\title{
RAPID
}

PUBLICATIONS

\section{Lymphocyte Adherence to Myelinated Tissue in Multiple Sclerosis}

\author{
Paula Dore-Duffy, Virginia Goertz, and Barbara L. Rothman, Department of \\ Neurology, University of Connecticut School of Medicine, \\ Farmington, Connecticut 06032
}

A B S T RACT A small subpopulation of human peripheral blood $\mathrm{T}$ lymphocytes has the capacity to adhere selectively to myelinated sections of human and nonhuman brain tissue. Adherence of lymphocytes from patients with multiple sclerosis is significantly greater than adherence of control lymphocytes. Monocytes inhibit binding in controls. This function appears to be lost by multiple sclerosis monocytes.

\section{INTRODUCTION}

Human peripheral blood lymphocytes from patients with multiple sclerosis (MS) ${ }^{1}$ adhere in significantly higher numbers to measles virus infected human epithelial cells than lymphocytes from healthy controls or patients with other diseases $(1,2)$. The phenomenon is not measles virus specific, ${ }^{2}$ requires viable monocytes, ${ }^{3}$ and is mediated by a prostaglandinsensitive mechanism $(3,4)$. It is not known whether increased lymphocyte adherence (LA) to virus-infected cells has a direct relationship to cytopathic mechanisms responsible for chronic demyelination observed in MS patients. Kuttner and Woodruff (5) reported that rat thoracic duct lymphocytes have the capacity to bind to myelinated sections of rat brain. It is likely

Received for publication 9 April 1980 and in revised form 14 July 1980.

${ }^{1}$ Abbreviations used in this paper: FCS, fetal calf serum; LA, lymphocyte adherence; MEM, Eagle's minimal essential medium; MS, multiple sclerosis; POX, peroxidase.

${ }^{2}$ Dore-Duffy, P.; and R. B. Zurier. Lymphocyte adherence to virus-infected cells. Manuscript submitted for publication.

${ }^{3}$ Dore-Duffy, P., and R. B. Zurier. Lymphocyte adherence in multiple sclerosis: role of monocytes. Clin. Immunol. Immunopathol. In press. that human lymphocytes also have a receptor for myelin. We examined peripheral blood lymphocytes from patients with MS and controls for adherence to calf and human brain sections. Results show that a small percentage of human $\mathrm{T}$ lymphocytes has the capacity to adhere selectively to myelin, and that this capacity is enhanced in patients with MS. Removal of monocytes increased adherence of control lymphocytes to white matter but did not affect adherence of MS lymphocytes. Experiments in which autologous or allogeneic monocytes were added back to monocyte-depleted cell suspensions indicated that monocyte-mediated control of LA to white matter is defective in MS patients.

\section{METHODS}

Patients and controls. Patients were evaluated in the University of Connecticut Health Center MS Clinic. "Definite" MS (6) patients not currently on steroids or nonsteroidal antiinflammatory agents were asked to participate. Controls were healthy volunteers from the university population. All donors stopped all medication for $48 \mathrm{~h}$. Fasting blood samples were taken between 8 and 9 a.m. Seven patients with neurological diseases other than MS included myasthenia gravis, central nervous system lupus, glioblastoma, Huntington's disease, senile dementia, and cerebrovascular disease. Donors were all age and sex matched.

Mononuclear cell isolation. Mononuclear cells were obtained from defibrinated venous blood by centrifugation on Ficoll-Hypaque gradients (LSM, Bionetics Laboratory Products, Litton Bionetics Inc., Kensington, Md.) (7). Cells were incubated at $37^{\circ} \mathrm{C}, 60 \mathrm{~min}$, washed, and resuspended in RPMI 1640 (Gibco Laboratories, Grand Island Biological Co., Grand Island, N. Y.) at $2-3 \times 10^{7}$ cells $/ \mathrm{ml}$.

Adherence to microexudate-coated flasks (8). Vero cells were grown to confluency in Eagle's Minimal Essential Medium (MEM) (Gibco) supplemented with 5\% fetal calf serum 
(FCS). Cells were fed daily with MEM $+20 \%$ FCS for $3-4 \mathrm{~d}$, then removed with $5 \mathrm{mM}$ EDTA. Flasks were rinsed thoroughly with MEM $+20 \%$ FCS. Mononuclear cells were added to flasks for $1 \mathrm{~h}$ at $37^{\circ} \mathrm{C}, \mathrm{pH}$ 7.4. Nonadherent cells were decanted, then treated as above. Monocytes were counted by staining for peroxidase (POX) activity (9). Mononuclear cells routinely had $10-15 \%$ POX-positive cells. Preparations with $<1 \%$ residual monocytes were used in experiments. Monocytes were removed with $5 \mathrm{mM}$ EDTA, washed, and counted.

Assay for adherence to brain. The adherence assay was performed according to Kuttner and Woodruff (5) with the modifications indicated. Fresh brain sections were cut coronally, embedded in O.C.T. (Lab-Tek Products, Naperville, Ill.) at $-20^{\circ} \mathrm{C}$, and $8-\mu \mathrm{m}$ sections were used. Slides were fixed with $1.5 \%$ glutaraldehyde in $0.1 \mathrm{M}$ sodium cacodylate buffer, $\mathrm{pH} 7.4,\left(10 \mathrm{~min}, 4^{\circ} \mathrm{C}\right)$, rinsed three times, or used without fixation. Slides were treated with $0.2 \mathrm{M}$ lysine (Fisher Scientific Co., Pittsburgh, Pa.) for $10 \mathrm{~min}$ at $4^{\circ} \mathrm{C}$, washed in cold buffer. $2 \times 10^{6}$ cells $/ 0.2 \mathrm{ml}$ were added per slide, gently rotated $(40 \mathrm{rpm})$ for $30 \mathrm{~min}$ at $4^{\circ} \mathrm{C}$. Nonadherent cells were removed with cold buffer. Slides were fixed with $1.5 \%$ glutaraldehyde and stained with Turks solution. LA was measured with a calibrated ocular grid (American Optical Corp., Buffalo, N. Y.), dimensions $10 \times 10$ $\mathrm{mm}$. Binding was determined from triplicate slides, 10 separate fields per slide. The density of lymphocytes bound per $10^{5} \mu \mathrm{m}^{2}$ and $10^{3} \mu \mathrm{m}^{2}$ was calculated.

E-Rosettes (10). Equal volumes of lymphocytes mixed with $0.5 \%$ sheep erythrocytes in MEM and FCS were incubated at $37^{\circ} \mathrm{C}$ for $30 \mathrm{~min}$, centrifuged, then incubated overnight at $4^{\circ} \mathrm{C}$. Lymphocytes were more than three sheep erythrocytes adhered were counted. E-rosette forming cells were removed by centrifugation on Ficoll-Hypaque gradients.

\section{RESULTS}

We examined control LA to glutaraldehyde-fixed sections of calf, rat, and human cerebrum and cerebellum, human heart, mouse liver, monkey kidney (CV-1), human amnion, and human epithelial cells. Adherence to most tissues was uniformly low and random ( $\leq 5$ lymphocytes $/ 10^{5} \mu \mathrm{m}^{2}$ ). Adherence to calf, rat, and human cerebrum and cerebellum was restricted to white matter (35-60 lymphocytes $/ 10^{5} \mu \mathrm{m}^{2}$ ) with no adherence to gray matter. LA to unfixed sections was slightly lower than fixed sections. All experiments were run on both fixed and unfixed tissue. Data represent adherence to fixed tissue.

Similar experiments were performed using MS lymphocytes (Table I). MS LA to human cerebellum was also restricted to white matter. However, adherence was higher than seen for controls (Table I; Fig. 1). The mean \pm SEM MS lymphocytes bound per unit area of white matter was $130 \pm 3.8$ lymphocytes/ $10^{5} \mu \mathrm{m}^{2}$ which is significantly $(P<0.01)$ different from the mean $\pm \operatorname{SEM}\left(41 \pm 2.9\right.$ lymphocytes $\left./ 10^{5} \mu \mathrm{m}^{2}\right)$ for controls (Table I). LA to the molecular layer (gray matter) was negligible (Fig. 1). Adherence to the granular layer was low. A slight overlap in values for controls and MS patients is seen. Similar results were seen with sections of cerebrum. LA in seven patients with other neurological illnesses was similar to controls $(45 \pm 4.0$ lymphocytes $\left./ 10^{5} \mu \mathrm{m}^{2}\right)$.
TABLE I

Comparison of LA to White Matter in Controls and Patients with Multiple Sclerosis

\begin{tabular}{lcccc}
\hline & No.* & $\begin{array}{c}\text { White } \\
\text { matter }\end{array}$ & $\begin{array}{c}\text { Granular } \\
\text { layer }\end{array}$ & $\begin{array}{c}\text { Molecular } \\
\text { layer }\end{array}$ \\
\hline Controls & & \multicolumn{3}{c}{${\text { Lymphocytes } / 10^{5}}_{\mu m^{2} \ddagger}$} \\
$\quad$ Calf cerebellum & 22 & $30 \pm 2.1$ & $16 \pm 1.8$ & $2 \pm 1.0$ \\
$\quad$ Human cerebellum & 10 & $41 \pm 2.9$ & $20 \pm 2.3$ & $4 \pm 2.4$ \\
MS patients & & & & \\
$\quad$ Calf cerebellum & 15 & $157 \pm 3.0 \$$ & $12 \pm 2.0$ & $5.2 \pm 2.0$ \\
$\quad$ Human cerebellum & 10 & $130 \pm 3.8 \S$ & $14 \pm 2.0$ & $3.0 \pm 1.0$ \\
\hline
\end{tabular}

* Number of individual donors tested in paired experiments. $\$$ Mean \pm SEM of patients tested. Individual means were calculated from the average of 10 separate fields per slide; three slides per demonstration.

$\$$ Significantly $(P<0.01$; Student's $t$ test) different from the mean \pm SEM for controls.

Optimal LA was seen with $\geq 2 \times 10^{6}$ cells $/ 0.2 \mathrm{ml}$. LA was first seen after 20 min incubation with control cells and 10 min incubation with MS cells. Maximum values were reached by $30-40 \mathrm{~min}$ and did not increase with prolonged incubation. It was impossible to determine accurately the percentage of lymphocyte binding to white matter, because total myelinated surface area varied per slide. Binding was slightly higher at $4^{\circ} \mathrm{C}$ than at room temperature.

Mononuclear cells from MS patients and controls were incubated overnight at $4^{\circ} \mathrm{C}$ with sheep erythrocytes (10). E-rosettes were removed by centrifugation on Ficoll-Hypaque gradients. Preparations with $<5 \%$ residual E-rosette-forming cells were used. Results indicate that removal of E-rosette-forming $T$ cells virtually eliminated all binding to white matter in controls $\left(58 \pm 3.8\right.$ to $5.5 \pm 2.2$ lymphocytes $\left./ 10^{5} \mu \mathrm{m}^{2}\right)$ and MS patients ( $106 \pm 6.0$ to $12 \pm 3.0$ ). Indirect immunofluorescent stains (unfixed slides) with goat anti-human immunoglobulin were negative for $B$ cells and removal of EAC rosettes did not alter LA. Monocytes did not bind to myelin in significant numbers. Thus, the adherent population appears to be a $\mathrm{T}$ cell.

When control cells adherent to Vero cell microexudate-coated surfaces (8) were removed, LA of nonadherent cells $(<1 \%$ monocytes) to white matter was increased. The mean \pm SEM LA per unit area of white matter was $143 \pm 8.6$ lymphocytes $/ 10^{5} \mu \mathrm{m}^{2}$ for depleted cells which was significantly different $(P<0.001)$ from $53 \pm 8.3$ lymphocytes $/ 10^{5} \mu \mathrm{m}^{2}$ for mononuclear cells. No effect was seen when MS monocytes were removed. The mean \pm SEM lymphocytes $/ 10^{5} \mu \mathrm{m}^{2}$ was $139 \pm 6.0$ for mononuclear cells and $108 \pm 8.0$ for monocyte-depleted preparations. Experiments were performed in which monocyte-depleted cell suspensions were reconstituted with 1 and $5 \%$ of autologous or age- and sex-matched allogeneic monocytes and then tested for their ability to bind to myelin (Table II). Control LA was reduced 

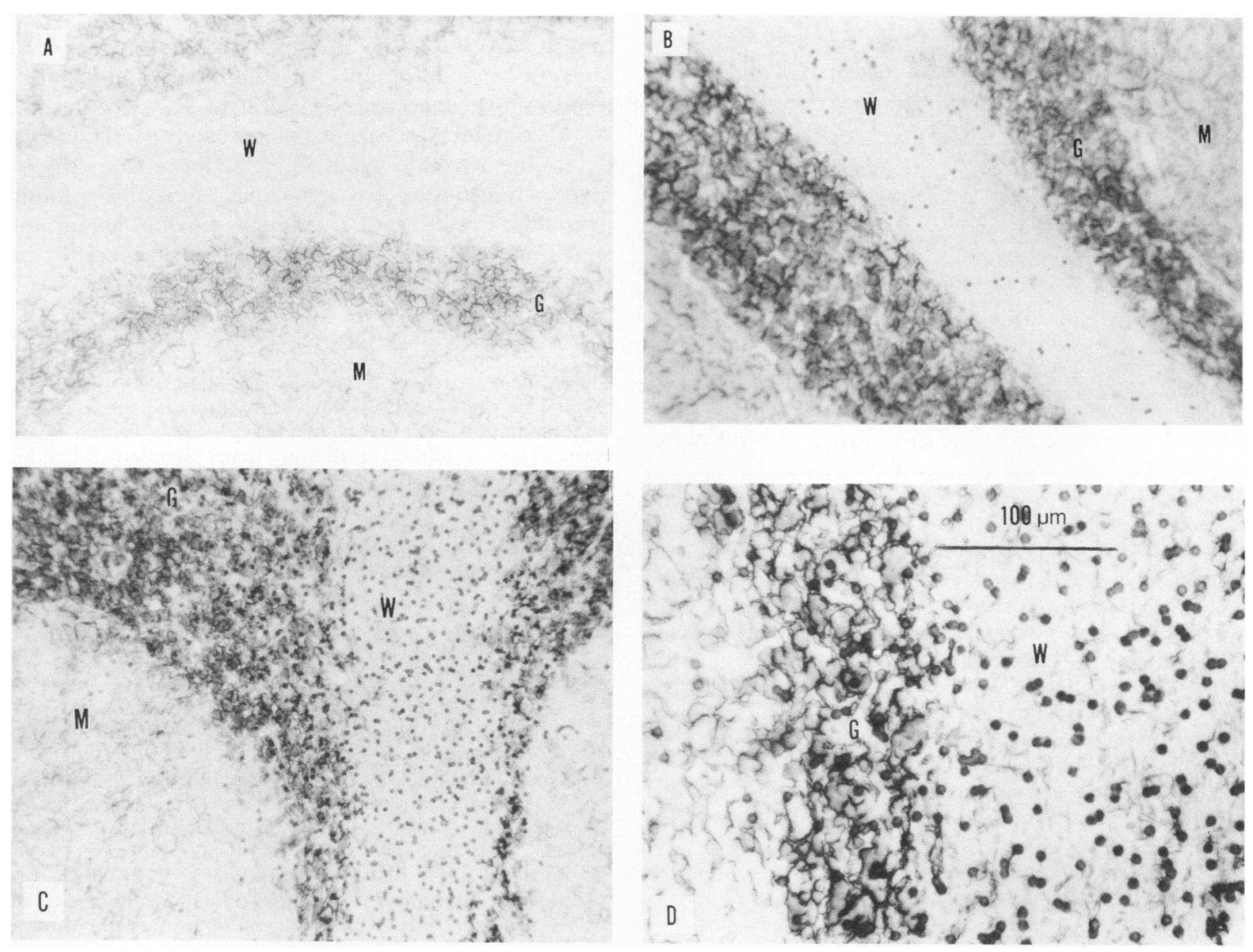

Figure 1 Lymphocyte adherence to human cerebellum: (A) Nonoverlaid section at $\times 45$, (B) overlaid with control PBL at $\times 45$, (C) overlaid with MS mononuclear cells at $\times 40$, and (D) at $\times 100$. Adherence is restricted to white matter $(\mathrm{W})$. Adherence to granular $(\mathrm{g})$ and molecular (M) layers is low. MS adherence is three to four times that seen in controls.

to normal levels by addition of 1 or $5 \%$ control monocytes. Addition of MS monocytes had no effect. MS LA was reduced to control levels by addition of $5 \%$ control monocytes, whereas addition of autologous monocytes at either concentration had no effect. $1 \%$ control monocytes did not always reduce adherence significantly. Results suggest that monocytemediated control of LA to myelin is defective in MS patients.

\section{DISCUSSION}

A population of circulating human $\mathrm{T}$ cells adheres preferentially to myelinated brain sections. This capacity is enhanced in MS T cells. No adherence was seen to the molecular layer (gray matter). MS lymphocytes seen in the granular layer of cerebellar cortex are probably adhered to myelinated fibers extending from the white matter. Therefore, human LA to white matter appears to depend on the presence of myelin, and may be comparable to similar observations seen with rat thoracic duct lymphocytes reported by Kuttner and Woodruff (5). It is possible that LA to white matter is a nonspecific cell-surface phenomenon, and not directed by antigen-reactive cells. In all experiments we were careful to exclude serum, and cells were incubated at $37^{\circ} \mathrm{C}$ for $60 \mathrm{~min}$ to remove cytophilic antibodies. It is possible that myelin-associated antibodies provided attachment sites for Fc-receptor-bearing cells. Although it is unlikely that the elevated and variable $T_{G}$ levels in MS reported by Santoli et al. (11) could account for the consistently observed differences between controls and patients in these studies, this possibility cannot be excluded. That binding was enhanced on glutaraldehyde-fixed sections suggests that adherence might be due to interactions of freealdehyde groups with cell surface proteins. However, binding was not altered after treatment of slides with lysine and adherence to myelin was observed on unfixed tissue. Similar glutaraldehyde-mediated effects were seen with rat thoracic duct lymphocytes (5) and further discussed by these same authors (12). 
TABLE II

LA to Human Cerebellum: Role of Monocytes

\begin{tabular}{lcr}
\hline \multicolumn{1}{c}{ Cell suspension } & Control & MS \\
\hline & \multicolumn{2}{c}{ Lymphocytes $10^{5} \mu m^{2 *}$} \\
Mononuclear & $41 \pm 6.2$ & $110 \pm 11.0$ \\
Monocyte depleted $\$$ & $93 \pm 8.4 \S$ & $97 \pm 15.0$ \\
$\begin{array}{l}\text { Reconstituted autologous } \\
\text { monocytes }\end{array}$ & & \\
$1 \%$ & $45 \pm 4.4$ & $115 \pm 12.0$ \\
$5 \%$ & $39 \pm 6.0$ & $135 \pm 11.0$ \\
Reconstituted allogeneic & & \\
monocytes & & \\
$1 \%$ & $85 \pm 6.4 \S$ & $57.5 \pm 10.0$ II \\
$5 \%$ & $64.4 \pm 10.0 \S$ & $38.0 \pm 8.0 \S$
\end{tabular}

* Mean \pm SEM; six paired experiments (six MS patients and six controls); individual values calculated from triplicate slides with 10 separate fields per slide.

$\$$ Monocytes depleted by adherence to microexudate-coated flasks (8). Mononuclear cells 10-15\% POX-positive cells; adherent monocytes $99 \%$ POX positive; nonadherent (monocyte depleted) $1 \%$ POX-positive cells.

$\$$ Significantly different $(P<0.001$; Student's $t$ test) from the mean \pm SEM for mononuclear cells.

"Monocyte-depleted cells were reconstituted with 1 and 5\% allogeneic (MS with control) or autologous (control with control) monocytes. Cell numbers adjusted to $2 \times 10^{6}$ total cells $/ 0: 2 \mathrm{ml}$ per slide. Viability determined by trypan blue stain.

I Significantly different ( $P=0.05$; Student's $t$ test) from the mean \pm SEM for MS mononuclear cells.

Monocyte removal from mononuclear cell suspensions enhanced control LA but had no significant effect on adherence of MS lymphocytes to white matter. These results suggest that either MS monocyte function is defective or that the MS T cell is not responsive to normal monocyte signals. Our recombination experiments to test this hypothesis tended to support defective monocyte function, but it should be noted that MS T cells did not respond as effectively to normal monocytes at $1 \%$ concentrations. These differences could be because the control monocytes were allogeneic. It is not known whether direct contact is necessary for monocyte control of adherence or whether there is a requirement for a soluble mediator. Studies to answer this question are in progress.

Monocytes are also required for LA to virus-infected cells. ${ }^{3}$ Monocyte removal results in decreased adherence to infected cells. Thus, different lymphocyte subpopulations and/or control mechanisms might regulate adherence to virus-infected cells. In fact, evidence not reported here indicates that removing cells that adhere to measles virus-infected human epithelial cells does not significantly alter LA to white matter (Dore-Duffy, unpublished observations). We have shown in the infected cell system that prostaglandins of the E series may be substituted for monocytes. However, we have not yet completely defined the role of prostaglandins in LA to myelin.

Although the precise mechanisms and specificity that determine why MS lymphocytes adhere so avidly to myelinated tissue are not clear, the observations presented in this paper should provide useful insights into the cytopathic mechanisms responsible for demyelination in MS.

\section{ACKNOWLEDGMENTS}

The authors wish to acknowledge Dr. Robert Zurier for his helpful suggestions, Dr. James Donaldson for neurological control samples, and Dr. Steven Pfeiffer for a sample of rat brain. They would also like to thank Randall Ribaudo, Tracey Koff, and Priscilla Adler for expert technical assistance.

This investigation was supported in part by a grant from the National Multiple Sclerosis Society, a grant from the Kroc Foundation, and by grant NS 14357 from the National Institutes of Health.

\section{REFERENCES}

1. Levy, N. L., P. S. Auerbach, and E. C. Hayes. 1976. A blood test for multiple sclerosis based on the adherence of lymphocytes to measles virus-infected cells. N. Engl. J. Med. 294: 1423-1427.

2. Dore-Duffy, P., R. B. Zurier, J. Donaldson, J. S. Nystrom, M. V. Viola, B. Rothman, and H. G. Thompson. 1979. Lymphocyte adherence in multiple sclerosis. Neurology. 29: 232-235.

3. Zurier, R. B., P. Dore-Duffy, and M. V. Viola. 1977. Adherence of human peripheral blood lymphocytes to measles infected cells. Enhancement by prostaglandin $E_{1}$. N. Engl. J. Med. 296: 1443-1446.

4. Dore-Duffy, P., and R. B. Zurier. 1979. Lymphocyte adherence in multiple sclerosis. Effect of aspirin. J. Clin. Invest. 63: 154-157.

5. Kuttner, B. J., and J. J. Woodruff. 1979. Selective adherence of lymphocytes to myelinated areas of rat brain. J. Immunol. 122: 1666-1671.

6. Schumacher, G. A., G. Beebe, R. F. Kilber, L. T. Kurland, J. F. Kurtze, F. McDowell, B. Nagler, W. A. Silbey, W. W. Tourtellotte, and T. L. Williams. 1965. Problems of experimental trials of therapy in multiple sclerosis: reported by the panel on evaluation of therapy in MS. Ann. N. Y. Acad. Sci. 122: 552-568.

7. Boyum, A. 1974. Separation of blood leukocytes, granulocytes and lymphocytes. Tissue Antigens. 4: 269274.

8. Ackerman, S. K., and S. D. Douglas. 1978. Purification of human monocytes on microexudate-coated surfaces. $J$. Immunol. 120: 1372-1374.

9. Kaplow, L. S. 1965. Simplified myeloperoxidase stain using benzidin hydrochloride. Blood. 25: 215-220.

10. Wybran, J., M. C. Carr, and H. H. Fudenberg. 1972. The human rosette-forming cell as a marker of a population of thymus-derived cells. J. Clin. Invest. 51: 2537-2543.

11. Santoli, D., L. Moretta, R. Lisak, D. Gilden, and H. Koprowski. 1978. Imbalances in T-cell subpopulations in multiple sclerosis patients. J. Immunol. 120: 13691371.

12. Woodruff, J. J., and R. A. Rasmussen. 1979. In vitro adherence of lymphocytes to unfixed and fixed high endothelial cells of lymph nodes. J. Immunol. 123: 23692372. 